Boise State University

ScholarWorks

Geosciences Faculty Publications and

Presentations

Department of Geosciences

$10-25-2014$

\title{
Eocene-Oligocene Latitudinal Climate Gradients in North America Inferred from Stable Isotope Ratios in Perissodactyl Tooth Enamel
}

\author{
Alessandro Zanazzi \\ Utah Valley University \\ Emily Judd \\ Utah Valley University \\ Andrew Fletcher \\ Utah Valley University \\ Harold Bryant \\ Royal Saskatchewan Museum \\ Matthew J. Kohn \\ Boise State University
}

NOTICE: this is the author's version of a work that was accepted for publication in Palaeogeography,

Palaeoclimatology, Palaeoecology. Changes resulting from the publishing process, such as peer review, editing, corrections, structural formatting, and other quality control mechanisms may not be reflected in this document. Changes may have been made to this work since it was submitted for publication. A definitive version was subsequently published in Palaeogeography, Palaeoclimatology, Palaeoecology, (In Press) doi: 10.1016/ j.palaeo.2014.10.024 


\title{
Eocene-Oligocene Latitudinal Climate Gradients in North America inferred from Stable Isotope Ratios in Perissodactyl Tooth Enamel
}

\author{
Alessandro Zanazzi* \\ Department of Earth Science \\ Utah Valley University \\ Orem, UT \\ Phone: (801) 863-5395 \\ e-mail: alessandro.zanazziuvu.edu \\ Emily Judd** \\ Department of Earth Science \\ Utah Valley University \\ Orem, UT \\ e-mail:emilyjudd28@gmail.com \\ Andrew Fletcher \\ Department of Earth Science \\ Utah Valley University \\ Orem, UT \\ e-mail: awfletcher711@gmail.com \\ Harold Bryant \\ Royal Saskatchewan Museum \\ Regina, SK \\ e-mail: Harold.Bryant@gov.sk.ca \\ Matthew Kohn \\ Department of Geosciences \\ Boise State University \\ Boise, ID \\ e-mail:mattkohn@boisestate.edu
}

* Corresponding author

** Now at Department of Earth Sciences, Syracuse University, Syracuse, NY

Keywords: Eocene-Oligocene, Climate, Perissodactyl, Stable Isotope, Tooth Enamel 


\begin{abstract}
The Eocene-Oligocene transition ( $34 \mathrm{Ma}$ ) was one of the most pronounced episodes of climate change of the Cenozoic. In order to investigate this episode of global climate cooling in North America, we analyzed the carbon and oxygen stable isotope composition of the carbonate component of 19 perissodactyl (horse and rhino) tooth enamel samples from the EoceneOligocene rocks of the Cypress Hills Formation (southwestern Saskatchewan, Canada); we then compared the results with previously published data from the US Great Plains (Nebraska, South Dakota, and Wyoming).

Average $( \pm 1 \sigma)$ perissodactyl enamel $\delta^{13} \mathrm{C}$ values (vs. V-PDB) in the Eocene $(-8.8 \pm 0.3 \%$ ) and Oligocene (-9.0 $\pm 0.3 \%$ ) are indistinguishable, suggesting no major change in mean annual precipitation in Saskatchewan across the transition. The $\delta^{13} \mathrm{C}$ values in Saskatchewan indicate the presence of arid ecosystems and are slightly higher than those in the US Great Plains, suggesting drier conditions at higher latitudes. With respect to oxygen isotopes, average $( \pm 1 \sigma)$ perissodactyl enamel $\delta^{18} \mathrm{O}$ values (vs. V-SMOW) in the Eocene (19.8 $\pm 2.0 \%$ ) and Oligocene $(20.1 \pm 3.6 \%$ ) are also indistinguishable, suggesting no change in the $\delta^{18} \mathrm{O}$ of meteoric precipitation across the transition in Saskatchewan. Enamel $\delta^{18} \mathrm{O}$ variability is much larger in the Oligocene vs. Eocene, indicating a large increase in temperature seasonality. This increase in enamel $\delta^{18} \mathrm{O}$ variability is much larger than that recorded in the US Great Plains, suggesting that higher latitudes are more sensitive to major episodes of climate change with respect to temperature seasonality. Finally, our data indicate no major change in the Oligocene vs. Eocene latitudinal gradient in local water $\delta^{18} \mathrm{O}$ in North America, which suggests no change in mean annual temperature gradients across the transition. This result supports the hypothesis that ascribes the climate change of the transition with a drop in atmospheric $p \mathrm{CO}_{2}$ because climate models show that this mechanism produces uniform cooling at mid-latitudes.
\end{abstract}




\section{Introduction}

Investigating Earth's climate history provides context to better understand ongoing climate change and helps predict future environmental conditions. As the transition between "greenhouse" and "icehouse" worlds, the Eocene-Oligocene transition (EOT; 34 Ma) is undoubtedly one the most important episodes of this history . The marine record of the transition has been studied for several decades and is generally well understood. The global oxygen isotope record of benthic foraminifera shows a $\sim 1.5 \%$ increase across the transition over $\sim 300 \mathrm{kyr}$ (Zachos et al., 2001), and has been interpreted to reflect a combination of deep seawater cooling and ice sheet growth on Antarctica. Recent studies show that the isotopic shift occurred in different steps, the first step (precursor event "EOT-1"; $33.8 \mathrm{Ma}$ ) was due largely to cooling whereas the following step (event "Oi-1"; $33.5 \mathrm{Ma}$ ) reflects a combination of cooling and ice sheet growth (Wade et al., 2012). A possible second precursor event (“EOT-2"; 33.6 Ma) may also reflect cooling of deep sea waters (Katz et al., 2008). The isotopic shifts are associated with a deepening of the carbonate compensation depth (CCD), likely caused by increased weathering of carbonate rocks in Antarctica (Basak and Martin, 2013; Coxall et al., 2005) and with extinctions and ecological reorganizations in many biological groups (see review of Coxall and Pearson, 2007). Two hypotheses have been formulated to explain the climate transition. One hypothesis attributes the cooling associated with the EOT to the opening of Southern Ocean gateways (Kennett, 1977), another with a drop in atmospheric $p \mathrm{CO}_{2}$ (DeConto and Pollard, 2003). Most recent studies support the $\mathrm{pCO}_{2}$ hypothesis in combination with orbital configurations favoring ice-sheet growth (Coxall et al., 2005; Liu et al., 2009; Pearson et al., 2009; Schouten et al., 2008; Zanazzi et al., 2007). 
The terrestrial record of the transition has received much less attention than the marine and seems to show strong spatial heterogeneity, with some areas showing little change to temperature or precipitation and others showing substantial cooling and/or drying (Dupont-Nivet et al., 2007; Grimes et al., 2005; Hren et al., 2013; Kocsis et al., 2014; Kohn et al., 2004; Xiao et al., 2010; Zanazzi et al., 2007). In addition, studies performed in the US Great Plains are characterized by some inconsistencies. Paleosol, paleontological, and sedimentological studies suggest significant aridification across the EOT (Evanoff et al., 1992; Retallack, 2007; Terry, 2001). In contrast, more recent isotopic studies indicate a large $\left(\sim 7^{\circ} \mathrm{C}\right)$ decrease in mean annual temperature (MAT) but no major change in aridity (Zanazzi et al., 2007; Zanazzi et al., 2009). Studies conducted in Europe and Greenland confirm the large cooling associated with the EOT (Eldrett et al., 2009; Hren et al., 2013; Schouten et al., 2008). Given the importance of this climatic event, it is necessary to further investigate the terrestrial climate record of the transition, particularly at higher latitude locations that are expected to be more sensitive to global climate change. The main purpose of this study is therefore to present new isotopic data of enamel from perissodactyl (horse and rhino) teeth collected in Eocene-Oligocene rocks of the Cypress Hills Formation (Saskatchewan, Canada), which preserves the northernmost record of the EOT in North America (Storer, 1994). The data presented here address the following specific questions regarding the EOT in North America:

1) What was the change in the $\delta^{18} \mathrm{O}$ of meteoric precipitation across the EOT in Saskatchewan? Zanazzi et al. (2007), Zanazzi and Kohn (2008), and Boardman and Secord (2013) presented tooth enamel $\delta^{18} \mathrm{O}$ data from the US Great Plains that suggested no change in average precipitation $\delta^{18} \mathrm{O}$ across the transition. Here we present similar data from the Cypress Hills to 
investigate whether higher latitudes responded similarly to the EOT climatic event with respect to precipitation $\delta^{18} \mathrm{O}$.

2) What were the latitudinal gradients in precipitation $\delta^{18} \mathrm{O}$ in North America in the Eocene and Oligocene? We compare average tooth enamel $\delta^{18} \mathrm{O}$ from the Cypress Hills and the US Great Plains to calculate latitudinal gradients in local water $\delta^{18} \mathrm{O}$ in North America during the Eocene and Oligocene. Because latitudinal gradients in precipitation $\delta^{18} \mathrm{O}$ mainly reflect gradients in temperature, these data may provide important insights on latitudinal MAT gradients in North America in the Eocene and Oligocene and on their change across the EOT.

3) What was the temperature seasonality in the Eocene and Oligocene in Saskatchewan? How did it change across the EOT? How does that compare with the change in the US Great Plains? Zanazzi et al. (2007) used the variability in tooth enamel $\delta^{18} \mathrm{O}$ data to calculate the temperature seasonality in the form of mean annual range of temperature (MART) in the Eocene and Oligocene in the US Great Plains. Here we use the same approach to estimate the MART in the Eocene and Oligocene in Saskatchewan. The comparison of the change in MART across the EOT at different latitudes may shed light on the latitudinal variability in temperature seasonality in a greenhouse vs. icehouse world.

4) What was the change in mean annual precipitation (MAP) across the EOT in Saskatchewan? Were there latitudinal gradients in MAP during the Eocene and Oligocene in North America? Kohn (2010) provided a quantitative relationship between modern C3 plant $\delta^{13} \mathrm{C}$ and MAP. We use tooth enamel $\delta^{13} \mathrm{C}$ to infer Eocene and Oligocene C3 plant composition and apply the equation presented by Kohn (2010) to calculate Eocene and Oligocene MAP in Saskatchewan and in the US Great Plains. We may therefore be able to determine whether significant changes 
in MAP occurred across the EOT in Saskatchewan and whether latitudinal gradients in MAP existed in the Eocene and Oligocene in North America.

The answers to these questions are important to investigate how mid-continents respond to major episodes of global climate change with respect to different climatic parameters.

\section{Background}

\section{1 Carbon isotopes in teeth}

Land plants are the sole source of carbon in mammalian herbivores so the carbon isotope composition of tooth enamel tracks the carbon isotope composition of the ingested plants (e.g., Cerling and Harris, 1999). In turn, the carbon isotope composition of land plants is mainly a function of the photosynthetic pathway used to fix atmospheric $\mathrm{CO}_{2}$ (Farquhar et al., 1989). The C3 pathway is the most common, occurring in all trees, almost all shrubs and herbs, and many grasses. Under modern conditions, with an atmospheric $\mathrm{CO}_{2} \delta^{13} \mathrm{C}$ of $-8 \%$, C3 plants have a mean $\delta^{13} \mathrm{C}$ value of about $-28.5 \pm 3 \%{ }^{1}$ (Kohn, 2010). There is no evidence for either C4 or CAM photosynthesis in the Eocene-Oligocene ecosystems we studied so they will not be considered here. C3 plants, under water stress conditions, close their stomata and show less discrimination against ${ }^{13} \mathrm{C}$. High $\delta^{13} \mathrm{C}$ values (up to $\sim-22 \%$ ) are therefore characteristic of open, arid habitats (Farquhar et al., 1989). Conversely, very negative $\delta^{13} \mathrm{C}$ values (down to $\sim-35 \%$ ) are found in humid closed canopy forests due to recycling of ${ }^{13} \mathrm{C}$-depleted $\mathrm{CO}_{2}$ and low irradiance (van der Merwe and Medina, 1991).

\footnotetext{
${ }^{1}$ All isotope composition are expressed with the conventional $\delta$ notation in which the ratio $\mathrm{R}$ of heavy to light isotopes in a sample (i.e., ${ }^{13} \mathrm{C} /{ }^{12} \mathrm{C}$ or $\left.{ }^{18} \mathrm{O} /{ }^{16} \mathrm{O}\right)$ is expressed as the parts per thousand or permil (\%) difference between the ratio in the sample $\left(\mathrm{R}_{\mathrm{sa}}\right)$ and the ratio in a standard $\left(\mathrm{R}_{\mathrm{st}}\right)$, normalized to $\mathrm{R}_{\mathrm{st}}: \delta=\left(\left(\mathrm{R}_{\mathrm{sa}} / \mathrm{R}_{\mathrm{st}}\right)-1\right)^{*} 1000$. In addition, all compositions are reported relative to the V-PDB $\left(\delta^{13} \mathrm{C}\right)$ and V-SMOW $\left(\delta^{18} \mathrm{O}\right)$ standards and all means are reported $\pm 1 \sigma$.
} 
Plant carbon ingested by herbivores is incorporated into the mineralized tissues of the animal. In mammals, these tissues have a mineralogy similar to hydroxyapatite $\left[\mathrm{Ca}_{5}\left(\mathrm{PO}_{4}\right)_{3}(\mathrm{OH})\right]$ with substitutions of $\mathrm{CO}_{3}$ for $\mathrm{PO}_{4}$ and $\mathrm{OH}$. The $\mathrm{CO}_{3}$ component of tooth enamel therefore assumes a $\delta^{13} \mathrm{C}$ value that reflects the carbon isotope composition of the ingested plants. However, both metabolism and biomineralization fractionate ingested carbon, resulting in bioapatites enriched in ${ }^{13} \mathrm{C}$ relative to the bulk diet. Variations in enrichments among animals may result from differences in digestive physiology and amount of methane produced; here we use an enrichment of $14.6 \pm 0.3 \%$ (Passey et al., 2005). The $\delta^{13} \mathrm{C}$ of atmospheric $\mathrm{CO}_{2}$ also affects plant $\delta^{13} \mathrm{C}$ so for atmospheric $\mathrm{CO}_{2} \delta^{13} \mathrm{C}$ values of $-6.0 \%$ (late Eocene) and -6.1\%o (early Oligocene; Tipple et al., 2010), C3 plant $\delta^{13} \mathrm{C}$ values would have ranged from about $-32.5 \%$ o to $-19.5 \%$. Thus, enamel $\delta^{13} \mathrm{C}$ values for pure C3 diets in the Eocene and Oligocene are expected to range from about -6 to $-18 \%$. Low (from $\sim-15$ to $-18 \%$ ) enamel $\delta^{13} \mathrm{C}$ values would indicate humid, closed-canopy forests, intermediate values (from -13 to $-8 \%$ ) might indicate woodlands, and high ( $>\sim-8 \%$ ) values would indicate dry ecosystems such as grasslands or scrublands.

\section{2 Oxygen isotopes in teeth}

The oxygen isotope composition of tooth enamel is widely used for paleoclimate investigations in continental areas (see review of Kohn and Cerling, 2002). The basis for these reconstructions is the correlation between the oxygen isotope composition of mammalian teeth and the composition of local meteoric precipitation which, at mid-latitudes, correlates with several factors including MAT, moisture source, and air mass trajectories. Several other physiological, environmental, and behavioral factors can affect tooth enamel $\delta^{18} \mathrm{O}$ (Kohn, 1996). The most critical of these factors is the degree of water dependence of the animal (Kohn, 1996; 
Levin et al., 2006). Whereas enamel $\delta^{18} \mathrm{O}$ in obligate drinkers shows a first-order dependence on the $\delta^{18} \mathrm{O}$ of meteoric precipitation, drought-tolerant animals usually deviate to higher values because they obtain proportionally more water from leaves which are more affected by evaporative enrichment relative to surface water. Because evaporative enrichment is inversely proportional to relative humidity, Levin et al. (2006) proposed using the difference in $\delta^{18} \mathrm{O}$ between obligate drinkers or "evaporation insensitive" (EI) taxa and drought tolerant or "evaporation sensitive" (ES) taxa as an index of terrestrial aridity.

In this study, we use the oxygen isotope composition of EI perissodactyls to reconstruct the composition of meteoric precipitation in Saskatchewan during the Eocene and Oligocene. Perissodactyls employ hind-gut fermentation, which is a relatively primitive feature that confers strong water-dependence (Kohn and Fremdt, 2007). Because of the additional factors that affect rainwater $\delta^{18} \mathrm{O}$ besides MAT in any given location (e.g., air mass trajectory, isotope composition of moisture source regions), we do not use precipitation $\delta^{18} \mathrm{O}$ to calculate changes in MAT across the EOT. However, we use enamel $\delta^{18} \mathrm{O}$ zoning to estimate temperature seasonality for specific times. In this context, since teeth mineralize progressively from the occlusal surface towards the root over time scales of months to a few years, intra-tooth isotopic profiles composed of subsamples collected along the growth axis of a tooth provide an estimate of the seasonal variability in precipitation $\delta^{18} \mathrm{O}$ which can be translated into temperature seasonality (Fricke et al., 1998; Zanazzi et al., 2007).

\section{Materials and methods}

\subsection{Samples and study sites}


A total of 19 teeth were analyzed in this study. These teeth belong to perissodactyls (horses and rhinos); some samples were identified only at the family level, others at the genus or species level. The teeth are from various fossil sites in the Cypress Hills Formation of southwestern Saskatchewan. These sites are within $\sim 20 \mathrm{~km}$ from each other and are at an elevation of $\sim 1,100$ m. The teeth from the Bud, Kealey Springs West (KSW), Parker Ranch/Alexander Ranch, Conglomerate Creek, Irish Springs and Calf Creek sites are late Eocene in age (Chadronian North American Land Mammal Age; NALMA), whereas the teeth from Fossil Bush and Anxiety Butte are early Oligocene in age (Orellan NALMA; Storer, 1996). The data from these teeth were compared with a more comprehensive dataset from the US Great Plains (Toadstool Park, Badlands National Park, and Torrington Quarry) and published in previous studies (Zanazzi et al., 2007; Zanazzi and Kohn, 2008). Figure 1 shows the location of the Cypress Hills Formation and the sampling sites of Zanazzi et al. (2007) and Zanazzi and Kohn (2008).

The Cypress Hills Formation rests unconformably on rocks of the late Cretaceous Bearpaw Formation and Paleocene Ravenscrag Formation. The Cypress Hills Formation spans almost 30 Myr, from 44 Ma (Eocene, Uinta NALMA) to 16 Ma (Miocene, Hemingfordian NALMA). It is on average $38 \mathrm{~m}$ thick and consists mainly of conglomerates and sandstones deposited in a braided river plain in a semiarid climate with seasonal rainfall. These coarse sediments derived originally from the Rocky Mountains during the Laramide orogeny and were remobilized during post-orogenic unloading and rebound. Subsequent transport reflects uplift by the EoceneOligocene intrusions of the Sweetgrass Hills, the Bearpaw Mountains, and the Highwood Mountains in Northern Montana (Leckie and Cheel, 1989).

\subsection{Sample preparation and isotope analyses}


Teeth were sampled by removing 2-3 mm wide vertical strips of enamel with a slow speed diamond-wafering saw. The enamel strips were sub-sampled perpendicular to the growth axis at intervals of $1.25 \mathrm{~mm}$ and the outer layer of enamel and adhering dentin were removed under a binocular microscope with a dental drill and a razor blade, respectively. Because of differences in tooth size and crown height, the number of analysable subsamples varied among the analysed teeth from 1 to 20. For the analyses of the carbonate component of enamel, powdered samples were treated with $\mathrm{H}_{2} \mathrm{O}_{2}$ to remove organic contaminants and with an acetic acid-calcium acetate buffer to remove diagenetic carbonates (Koch et al., 1997). A recent study confirms that this treatment protocol produces the best results (Crowley and Wheatley, 2014). Following the treatment, the samples were dissolved in phosphoric acid and analyzed in the SIRFER lab of the University of Utah. Precision of these analyses is typically better than $\pm 0.2 \%$ o $(1 \sigma)$.

\section{Results}

Summary descriptive statistics for the analyzed Cypress Hills teeth are reported in Table 1 (Eocene samples) and Table 2 (Oligocene samples). Both parametric (two-tailed heteroscedastic t-tests for central values and F-tests for variances) and non-parametric (two-tailed MannWhitney tests for central values and Levene tests for variances) statistical tests were performed on the data. Statistical significance is based on $\mathrm{p}<0.05$.

\subsection{Carbon isotopes}

Figure 2 shows box and whiskers plots for Eocene and Oligocene perissodactyl $\delta^{13} \mathrm{C}$ for the Cypress Hills and the US Great Plains. The $\delta^{13} \mathrm{C}$ values of Cypress Hills horses in the Eocene range from $-9.7 \%$ o to $-8.3 \%$ and average $-8.9 \pm 0.4 \%$ whereas Eocene rhino $\delta^{13} \mathrm{C}$ values range 
from $-9.2 \%$ to $-8.2 \%$ and average $-8.8 \pm 0.3 \%$. Eocene average $\delta^{13} \mathrm{C}$ of horses vs. rhinos is not statistically different ( $\mathrm{p}=0.47$ t-test; $\mathrm{p}=0.49$ Mann-Whitney test). With respect to Oligocene data, horse $\delta^{13} \mathrm{C}$ values range from $-10.6 \%$ to $-8.7 \%$ and average $-9.4 \pm 0.6 \%$; rhino $\delta^{13} \mathrm{C}$ values range from $-9.2 \%$ to $-8.2 \%$ and average $-8.6 \pm 0.2 \%$. Oligocene average $\delta^{13} \mathrm{C}$ of horses vs. rhinos is statistically different ( $<<0.01 \mathrm{t}$ - and Mann-Whitney tests). Eocene vs. Oligocene average $\delta^{13} \mathrm{C}$ is statistically different for both horses ( $\mathrm{p}=0.001$ t-test; $\mathrm{p}=0.002$ Mann-Whitney test) and rhinos ( $p=0.04$ t-test; $p=0.01$ Mann-Whitney test) separately. However, when horse and rhino data are pooled into perissodactyl datasets, average Eocene $\left(-8.8 \pm 0.3 \%\right.$ ) and Oligocene $(-9.0 \pm 0.5 \%) \delta^{13} \mathrm{C}$ values are not statistically different ( $\mathrm{p}=0.15$ t-test; $\mathrm{p}=0.76$ Mann-Whitney test). With respect to variability, intra-tooth isotope profiles generally show a very small $\delta^{13} \mathrm{C}$ range in both the Eocene and Oligocene (Figs. 3 and 4). However, variance in perissodactyl $\delta^{13} \mathrm{C}$ is higher in the Oligocene than in the Eocene ( $\mathrm{p}<0.001$ F-test; $\mathrm{p}=0.082$ Levene test). When compared with data from Zanazzi et al. (2007) and Zanazzi and Kohn (2008), we generally find significantly higher perissodactyl average $\delta^{13} \mathrm{C}$ in the Cypress Hills than in the US Great Plains in both the Eocene $(\mathrm{p}<0.001 \mathrm{t}$-test; $\mathrm{p}=0.61$ Mann-Whitney test) and Oligocene $(\mathrm{p}<0.001 \mathrm{t}-$ and Mann-Whitney tests). In addition, we find higher variability in perissodactyl $\delta^{13} \mathrm{C}$ in the US Great Plains relative to the Cypress Hills in both the Eocene and Oligocene (Fig. 2; $<<0.001$, F- and Levene tests).

\subsection{Oxygen isotopes}

Figure 5 shows box and whiskers plots for Eocene and Oligocene perissodactyl $\delta^{18} \mathrm{O}$ in the Cypress Hills and the US Great Plains. The $\delta^{18} \mathrm{O}$ values of Cypress Hills horses in the Eocene range from $17.6 \%$ to $25.1 \%$ and average $21.3 \pm 2.3 \%$; Eocene rhino $\delta^{18} \mathrm{O}$ values range from $16.1 \%$ o to $21.1 \%$ and average $19.1 \pm 1.3 \%$. Eocene average $\delta^{18} \mathrm{O}$ of horses vs. rhinos is 
statistically different ( $\mathrm{p}=0.001 \mathrm{t}$ - and Mann-Whitney tests). With respect to Oligocene data, horse $\delta^{18} \mathrm{O}$ values range from $19.5 \%$ to $27.0 \%$ and average $23.7 \pm 2.1 \%$; rhino $\delta^{18} \mathrm{O}$ values range from $14.4 \%$ o to $21.6 \%$ and average $17.7 \pm 2.0 \%$. Oligocene average $\delta^{18} \mathrm{O}$ of horses vs. rhinos is statistically different ( $<<0.01 \mathrm{t}$ - and Mann-Whitney tests). Similar to $\delta^{13} \mathrm{C}$ values, Eocene vs. Oligocene average $\delta^{18} \mathrm{O}$ is different for horses and rhinos separately (horses: $\mathrm{p}=0.002 \mathrm{t}$ - and Mann-Whitney tests; rhinos: $\mathrm{p}=0.001 \mathrm{t}$ - and Mann-Whitney tests) but not for the whole perissodactyl datasets ( $\mathrm{p}=0.61 \mathrm{t}$-test; $\mathrm{p}=0.89$ Mann-Whitney test). With respect to variability, intra-tooth profiles (Figs. 3 and 4) show a much higher range in $\delta^{18} \mathrm{O}$ than in $\delta^{13} \mathrm{C}$ and variance in the perissodactyl $\delta^{18} \mathrm{O}$ datasets is remarkably higher in the Oligocene $(12.8 \%$ ) than in the Eocene (3.9\% ; $\mathrm{p}<0.001 \mathrm{~F}-$ and Levene tests). Relative to the US Great Plains data, we find lower perissodactyl $\delta^{18} \mathrm{O}$ in the Cypress Hills in both the Eocene and Oligocene $(\mathrm{p}<0.001 \mathrm{t}$ - and MannWhitney tests). The difference between the average perissodactyl $\delta^{18} \mathrm{O}$ in the Cypress Hills and in the US Great Plains is, however, similar for the Eocene (5.1 $\pm 2.4 \%$ ) and Oligocene $\left(4.3 \pm 4.0 \%\right.$ ). Finally, we find higher perissodactyl $\delta^{18} \mathrm{O}$ variability in the Cypress Hills than in the US Great Plains in both the Eocene and Oligocene ( $<<0.001 \mathrm{~F}$ - and Levene tests)

\section{Discussion}

The changes in average $\delta^{13} \mathrm{C}$ and $\delta^{18} \mathrm{O}$ values across the EOT for horses and rhinos are opposite. More specifically, whereas horse average $\delta^{18} \mathrm{O}$ increases across the EOT (from 21.3\%o to $23.7 \%$ ), rhino average value decreases (from $19.1 \%$ o to $17.7 \%$ ). Similarly, whereas the average $\delta^{13} \mathrm{C}$ of horses decreases from the Eocene (-8.9\%o) to the Oligocene (-9.4\%o), rhino average $\delta^{13} \mathrm{C}$ increases, albeit only slightly (from $-8.8 \%$ to $-8.6 \%$ ). These opposite changes may be due to migration of the animals or simply to noise in the data, a feature found in other 
analogous datasets. For example, in an isotope study of fossil teeth in central Oregon (Kohn and Fremdt, 2007), small numbers of analyses for horses appear to bias data scatter and mean values relative to sympatric rhinos and similarly-sized oreodonts. A pooled dataset, however, gives more realistic values. Similarly, comparison of horses and rhinos at Toadstool Park fails to resolve a consistent isotopic offset, but rather indicates considerable scatter (Zanazzi et al., 2007; Zanazzi and Kohn, 2008; Boardman and Secord, 2013). As a consequence, to improve signal-tonoise, we pooled the data for horses and rhinos and discuss them in terms of perissodactyls datasets. Similar water dependencies of horses and rhinos (both are EI taxa; Levin et al., 2006) and similar habitat and diet (Zanazzi and Kohn, 2008) support this choice; the pooled datasets also provide the minimal number of samples required to accurately reconstruct paleoclimates and paleoenvironments (Hoppe et al., 2005).

\subsection{Carbon isotopes}

The $\delta^{13} \mathrm{C}$ data presented here are consistent with an expected pure C3 diet for the investigated perissodactyls. In C3 plants, $\delta^{13} \mathrm{C}$ values mainly reflect aridity and degree of vegetation openness. Therefore, the indistinguishable Eocene vs. Oligocene average perissodactyl $\delta^{13} \mathrm{C}$ in Saskatchewan suggests no major change in aridity across the EOT, confirming the results of Zanazzi et al. (2007) for the US Great Plains. In addition, high $\delta^{13} \mathrm{C}$ values are consistent with relatively dry environments in both the Eocene and Oligocene. The higher variability in Oligocene vs. Eocene perissodactyl $\delta^{13} \mathrm{C}$ values may indicate more variable precipitation and longer dry periods in the Oligocene than in the Eocene, although intra-tooth profiles show very small variability in both time periods. The higher average $\delta^{13} \mathrm{C}$ in Cypress Hills relative to the US Great Plains likely imply slightly drier condition at higher latitudes. Finally, the larger 
variability in perissodactyl $\delta^{13} \mathrm{C}$ in the US Great Plains relative to the Cypress Hills likely reflects the presence of a higher variety of ecosystems, given the larger spatial spread of the sampling sites in the US Great Plains.

The equation provided by Kohn (2010) can be rearranged to calculate MAP's based on enamel $\delta^{13} \mathrm{C}$ :

$$
\operatorname{MAP}\left(\frac{m m}{y r}\right)=10^{-\frac{\delta 13 C_{C 3}+10.29+(0.0124 \times A b s . L a t i t u d e)-\left(1.9 \times 10^{-4} \times \text { Altitude }\right)}{5.61}}-300
$$

Using a value of $14.6 \%$ for the enrichment in ${ }^{13} \mathrm{C}$ between enamel and diet for the perissodactyls (Passey et al., 2005) and offsets of 2\%o (Eocene) and 1.9\%o (Oligocene) between the $\delta^{13} \mathrm{C}$ of modern and Eocene-Oligocene $\mathrm{CO}_{2}$ (Tipple et al., 2010; i.e., $\delta^{13} \mathrm{C}_{\mathrm{C} 3 \text { Eocene }}=\delta^{13} \mathrm{C}_{\text {enamel }}{ }^{-}$

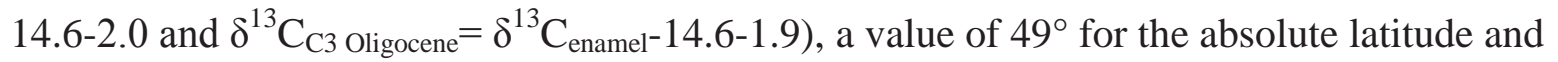
1,100 $\mathrm{m}$ for the altitude, we calculated MAP values of $127 \mathrm{~mm} / \mathrm{yr}$ in the Eocene and $130 \mathrm{~mm} / \mathrm{yr}$ in the Oligocene in the Cypress Hills. For the US Great Plains (latitude $=43^{\circ}$, altitude $=1370 \mathrm{~m}$ ), we calculated MAP values of 215 mm/yr and 230 mm/yr for the Eocene and Oligocene, respectively. Although the uncertainties associated with these numbers are large (approximately half the calculated value; Kohn and McKay, 2012) these values are unrealistically low. Several possibilities might explain these low values, the most likely being an unknown diagenetic effect affecting enamel $\delta^{13} \mathrm{C}$ or an incorrect estimate of atmospheric $\mathrm{CO}_{2} \delta^{13} \mathrm{C}$ from benthic foraminifera. Further studies are required to resolve this issue.

\subsection{Oxygen isotopes}

As seen in the US Great Plains (Zanazzi et al., 2007; Zanazzi and Kohn, 2008; Boardman and Secord, 2013), the average enamel $\delta^{18} \mathrm{O}$ of the perissodactyls from the Cypress Hills does not change across the EOT, suggesting no change in local water composition. Because seawater 
$\delta^{18} \mathrm{O}$ increased by $\sim 1 \%$ due to the ice volume effect across the transition (Katz et al., 2008), the $\delta^{18} \mathrm{O}$ of precipitation decreased by $\sim 1 \%$ relative to seawater. This decrease might indicate either a small MAT decrease across the transition in Saskatchewan if aridity and atmospheric circulation did not change (which seems unlikely), or a larger decrease along with a shift in atmospheric circulation. Without independent knowledge of temperature (e.g., from an independent isotope proxy), moisture sources, air mass trajectories and aridity, $\delta^{18} \mathrm{O}$ shifts of tooth enamel or local water cannot be interpreted in terms of temperature change alone. This fact is well established in the literature. For example, shifting moisture patterns plus ice volume during the Last Glacial Maximum drove a $\sim 1 \%$ increase in $\delta^{18} \mathrm{O}$ values of precipitation in Texas relative to today despite a $\sim 4^{\circ} \mathrm{C}$ lower MAT (Koch et al., 2004; Braconnot et al., 2007; Kohn and McKay, 2010). Similarly, a decrease in MAT of $4-6^{\circ} \mathrm{C}$ in England across the EOT produced no resolvable change to local water compositions (Hren et al., 2013). Thus, assertions that quasiconstant enamel isotope compositions from the Great Plains preclude large temperature changes across the EOT (e.g., Boardman and Secord, 2013) are unfounded.

With respect to seasonality, variability in Oligocene vs. Eocene perissodactyl $\delta^{18} \mathrm{O}$ values increased markedly, suggesting either a substantial increase in temperature seasonality across the EOT in Saskatchewan or a shift in seasonal moisture sources (i.e., proportions of moisture sources from the Gulf of Mexico vs. from the Pacific Ocean and from the continental polar/arctic regions). This increase in variability is much larger than that recorded in the US Great Plains, suggesting a larger sensitivity of higher latitudes to episodes of global climate change, at least with respect to seasonality. If the variation is ascribed solely to temperature seasonality, then the 5-95 percentile interval of an entire $\delta^{18} \mathrm{O}$ enamel dataset can be used to estimate intra-annual temperature variability. This interval can then be used, along with a temperature coefficient of 
seasonal variations in precipitation $\delta^{18} \mathrm{O}$ and a damping factor that accounts for the residence time of $\mathrm{O}_{2}$ in the animals, to estimate the MART at a given location. These estimates carry large uncertainties, in part because they do not account either for the damping effect of the enamel maturation process and averaging compositions in large water bodies (i.e., rivers and lakes) or for increased variation in leaf water $\delta^{18} \mathrm{O}$ in response to seasonal changes in humidity (Kohn, 1996). Nevertheless, using the perissodactyl 5-95 percentile interval for the Eocene ( $\mathrm{r}=6.1 \%$ ) and Oligocene $\left(\mathrm{r}=10.5 \%\right.$ ), a temperature coefficient for seasonal variation in precipitation $\delta^{18} \mathrm{O}$ (c) equal to $0.3 \% /{ }^{\circ} \mathrm{C}$ (Kohn and Welker, 2005), a dampening factor (d) of 0.9 (Kohn et al., 2002), and a slope (m) for the line of modern perissodactyls $\delta^{18} \mathrm{O}$ vs. local water $\delta^{18} \mathrm{O}$ of 0.96 (this value is the average of horses and rhinos; Tutken et al., 2006 and Zanazzi et al., 2007), MART can be calculated using the following equation:

$$
M A R T \geq \frac{r \times m}{c \times d}
$$

MART values in Saskatchewan apparently increase from $21.7^{\circ} \mathrm{C}$ (Eocene) to $37.3^{\circ} \mathrm{C}$

(Oligocene). The Oligocene value is similar to the modern MART in Regina, SK $\left(35^{\circ} \mathrm{C}\right.$; $\mathrm{NCDC}$, 2009). The apparent increase in MART across the transition in Saskatchewan far exceeds that recorded in the US Great Plains (from $21.9^{\circ} \mathrm{C}$ to $25.8^{\circ} \mathrm{C}$; Zanazzi et al., 2007) and that calculated in coastal areas. For example, Eldrett et al. (2009) found an increase in MART of $\sim 8^{\circ} \mathrm{C}$ in Greenland whereas Ivany et al. (2000) found an increase of $\sim 4^{\circ} \mathrm{C}$ in the US Gulf coastal plain. With respect to latitudinal gradients, the difference between the $\delta^{18} \mathrm{O}$ values in the US Great Plains vs. Saskatchewan (4-5\%) does not resolvably change from the Eocene to Oligocene. Gradients in local water $\delta^{18} \mathrm{O}$ in the mid-continents mainly reflect gradients in MAT, and if the same principles hold for the Eocene-Oligocene, our data suggest no change in latitudinal MAT gradients across the EOT in North America. This finding supports the $\mathrm{CO}_{2}$ hypothesis as a causal 
mechanism for the climate change across the EOT because model experiments predict uniform cooling at these latitudes with decreasing atmospheric $\mathrm{CO}_{2}$ levels (Rind, 1986).

We used here the relationship between rainwater $\delta^{18} \mathrm{O}$ and the $\delta^{18} \mathrm{O}$ of the carbonate component of enamel calculated for modern horses and rhinos to estimate a value for rainwater $\delta^{18} \mathrm{O}$ in Saskatchewan. The equation for horses is the following (Zanazzi et al., 2007):

$$
\delta 180_{\text {water }}=1.16 \delta 180_{\text {enamel }}-36.4
$$

Whereas that for rhino is (Tütken et al., 2006):

$$
\delta 180_{\text {water }}=0.76 \delta 180_{\text {enamel }}-25.64
$$

Using these equations, the average $\delta^{18} \mathrm{O}$ value for horses (22.7\%) and rhinos (18.4\%o), we found a value for local water $\delta^{18} \mathrm{O}$ in Saskatchewan of $-10.1 \%$ (horses) and $-11.7 \%$ (rhinos). Taking an average of the two values $(-10.9 \%)$, and a value calculated for the US Great Plains (-8.2\%o;

Zanazzi et al., 2007) yields a latitudinal gradient in local water $\delta^{18} \mathrm{O}$ of approximately $0.45 \%$ o $/{ }^{\circ}$ lat. This gradient is slightly lower than the modern value for precipitation $\left(0.6 \% /{ }^{\circ}\right.$ lat $)$, is similar to values previously calculated for the Eocene $\left(0.4 \% /{ }^{\circ}\right.$ lat; Fricke and Wing, 2004), and is higher than values calculated for the mid-Cretaceous greenhouse $\left(\sim 0.3 \%{ }^{\circ} /{ }^{\circ}\right.$ at; Suarez et al., 2012). These observations generally support the view that global cooling increases latitudinal temperature and isotopic gradients, at least at mid-latitudes.

\section{Conclusions}

New data are presented for the carbon and oxygen stable isotope composition of the carbonate component of enamel from rhino and horse teeth collected in the Eocene-Oligocene rocks of the Cypress Hills Formation (Saskatchewan, Canada) and compared with previously published data from the US Great Plains. Our data indicate that: 
1) Average precipitation $\delta^{18} \mathrm{O}$ did not change across the Eocene-Oligocene transition in Saskatchewan, similar to observations in the US Great Plains (Zanazzi et al., 2007). This result suggests that higher and lower latitudes in North America responded similarly to the climatic change associated with the transition with respect to average precipitation $\delta^{18} \mathrm{O}$.

2) Latitudinal gradients in precipitation $\delta^{18} \mathrm{O}$ in North America did not change across the Eocene-Oligocene transition. We calculate a value of $0.45 \% /{ }^{\circ}$ lat for both the Eocene and Oligocene. This result supports the hypothesis that ascribes the climate cooling across the EOT to a drop in atmospheric $p \mathrm{CO}_{2}$, as this mechanism is expected to produce uniform cooling at mid-latitudes.

3) Temperature seasonality increased greatly across the Eocene-Oligocene transition in Saskatchewan. This increase is much larger than that recorded in the US Great Plains, suggesting that temperature seasonality at higher latitudes responds more sensitively to major episodes of climate change.

4) Mean annual precipitation did not change substantially across the Eocene-Oligocene transition in both Saskatchewan and the US Great Plains. Precipitation was probably slightly lower in Saskatchewan in both the Eocene and Oligocene and values are characteristic of very dry ecosystems.

\section{Acknowledgements}

The authors thank Brad Erkkila and Suvankar Chakraborty for performing the isotope analyses, the Royal Saskatchewan Museum for allowing the partially destructive analyses of the fossil teeth, and two anonymous reviewers for providing comments that improved the quality of this 
manuscript. The project was funded by UVU Scholarly Activity Grants to AZ and EJ and by

NSF grants EAR1251443 and EAR1321897 to MJK

\section{References}

Basak, C., Martin, E.E., 2013. Antarctic weathering and carbonate compensation at the EoceneOligocene transition. Nature Geoscience 6, 121-124.

Boardman, G.S., Secord, R., 2013. Stable isotope paleoecology of White River ungulates during the Eocene-Oligocene climate transition in northwestern Nebraska. Palaeogeography, Palaeoclimatology, Palaeoecology 375, 38-49.

Cerling, T.E., Harris, J.M., 1999. Carbon isotope fractionation between diet and bioapatite in ungulate mammals and implications for ecological and paleoecological studies. Oecologia 120, 347-363.

Coxall, H., Pearson, P., 2007. The Eocene-Oligocene transition. Deep Time Perspectives on Climate Change: Marrying the Signal From Computer Models and Biological Proxies, edited by M. Williams et al, 351-387.

Coxall, H.K., Wilson, P.A., Palike, H., Lear, C.H., Backman, J., 2005. Rapid stepwise onset of Antarctic glaciation and deeper calcite compensation in the Pacific Ocean. Nature 433, 53-57. Crowley, B.E., Wheatley, P.V., 2014. To bleach or not to bleach? Comparing treatment methods for isolating biogenic carbonate. Chemical Geology.

DeConto, R.M., Pollard, D., 2003. Rapid Cenozoic glaciation of Antarctica induced by declining atmospheric CO2. Nature 421, 245-249.

Dupont-Nivet, G., Krijgsman, W., Langereis, C.G., Abels, H.A., Dai, S., Fang, X., 2007. Tibetan plateau aridification linked to global cooling at the Eocene-Oligocene transition. Nature 445, 635-638.

Eldrett, J.S., Greenwood, D.R., Harding, I.C., Huber, M., 2009. Increased seasonality through the Eocene to Oligocene transition in northern high latitudes. Nature 459, 969-973.

Evanoff, E., Prothero, D.R., Lander, R.H., 1992. Eocene-Oligocene climatic change in North America: the White River Formation near Douglas, East-Central Wyoming, in: Prothero, D.R., Berggren, W.A. (Eds.), Eocene-Oligocene Climatic and Biotic Evolution. Princeton University Press, Princeton, NJ, pp. 116-130.

Farquhar, G.D., Ehleringer, J.R., Hubick, K.T., 1989. Carbon isotope discrimination and photosynthesis. Annual Review of Plant Physiology and Molecular Biology 40, 503-537.

Fricke, H.C., Clyde, W.C., O'Neil, J.R., 1998. Intra-tooth variations in $\delta^{18} \mathrm{O}\left(\mathrm{PO}_{4}\right)$ of mammalian tooth enamel as a record of seasonal variations in continental climate variables. Geochimica et Cosmochimica Acta 62, 1839-1850.

Grimes, S.T., Hooker, J.J., Collinson, M.E., Mattey, D.P., 2005. Summer temperatures of late Eocene to Oligocene freshwaters. Geology 33, 189-192.

Hoppe, K.A., Stuska, S., Amundson, R., 2005. The implications for paleodietary and paleoclimatic reconstructions of intrapopulation variability in the oxygen and carbon isotopes of teeth from modern feral horses. Quaternary Research 64, 138-146. 
Hren, M.T., Sheldon, N.D., Grimes, S.T., Collinson, M.E., Hooker, J.J., Bugler, M., Lohmann, K.C., 2013. Terrestrial cooling in Northern Europe during the Eocene-Oligocene transition. Proceedings of the National Academy of Sciences 110, 7562-7567.

Ivany, L.C., Patterson, W.P., Lohmann, K.C., 2000. Cooler winters as a possible cause of mass extinctions at the Eocene/Oligocene boundary. Nature 407, 887-890.

Katz, M.E., Miller, K.G., Wright, J.D., Wade, B.S., Browning, J.V., Cramer, B.S., Rosenthal, Y., 2008. Stepwise transition from the Eocene greenhouse to the Oligocene icehouse. Nature Geoscience 1, 329-334.

Kennett, J.P., 1977. Cenozoic evolution of Antarctic glaciation, the circum-antarctic ocean, and their impact on global paleoceanography. Journal of Geophysical Research 82, 3843-3860.

Koch, P.L., Diffenbaugh, N.S., Hoppe, K.A., 2004. The effects of late Quaternary climate and< $\mathrm{i}>\mathrm{p}</ \mathrm{i}>\mathrm{CO}<$ sub $>2</$ sub $>$ change on $\mathrm{C}<$ sub $>4</$ sub $>$ plant abundance in the south-central United States. Palaeogeography, Palaeoclimatology, Palaeoecology 207, 331-357.

Koch, P.L., Tuross, N., Fogel, M.L., 1997. The effects of sample treatment and diagenesis on the isotopic integrity of carbonate in biogenic hydroxylapatite. Journal of Archaeological Science 24, 417-429.

Kocsis, L., Ozsvart, P., Becker, D., Ziegler, R., Scherler, L., Codrea, V., 2014. Orogeny forced terrestrial climate variation during the late Eocene-early Oligocene in Europe. Geology 42, 727730.

Kohn, M.J., 1996. Predicting animal $\delta^{18} \mathrm{O}$ : accounting for diet and physiological adaptation. Geochimica et Cosmochimica Acta 60, 4811-4829.

Kohn, M.J., 2010. Carbon isotope composition of terrestrial C3 plants as indicators of (paleo)ecology and (paleo)climate. Proceedings of the National Academy of Sciences 107, 19691-19695.

Kohn, M.J., Cerling, T.E., 2002. Stable isotope compositions of biological apatite, Phosphates. Geochemical, Geobiological, and Materials Importance. Mineralogical Society of America, pp. 455-488.

Kohn, M.J., Fremdt, T.J., 2007. Tectonic controls on isotope compositions and species diversification, John Day Basin, central Oregon. Paleobios 27, 48-61.

Kohn, M.J., Josef, J.A., Madden, R., Kay, R., Vucetich, G., Carlini, A.A., 2004. Climate stability across the Eocene-Oligocene transition, southern Argentina. Geology 32, 621-624.

Kohn, M.J., McKay, M., 2010. Stable isotopes of fossil teeth corroborate key general circulation model predictions for the Last Glacial Maximum in North America. Geophysical Research Letters 37, n/a-n/a.

Kohn, M.J., McKay, M.P., 2012. Paleoecology of late Pleistocene-Holocene faunas of eastern and central Wyoming, USA, with implications for LGM climate models. Palaeogeography, Palaeoclimatology, Palaeoecology 326-328, 42-53.

Kohn, M.J., Miselis, J.L., Fremd, T.J., 2002. Oxygen isotope evidence for progressive uplift of the Cascade Range, Oregon. Earth and Planetary Science Letters 204, 151-165.

Kohn, M.J., Welker, J.M., 2005. On the temperature correlation of $\delta^{18} \mathrm{O}$ in modern precipitation. Earth and Planetary Science Letters 231, 87-96.

Leckie, D.A., Cheel, R.J., 1989. The Cypress Hills Formation (upper Eocene to Miocene): a semi-arid braidplain deposit resulting from intrusive uplift. Canadian Journal of Earth Sciences 26, 1918-1931. 
Levin, N.E., Cerling, T.E., Passey, B.H., Harris, J.M., Ehleringer, J.R., 2006. A stable isotope aridity index for terrestrial environments. Proceedings of the National Academy of Sciences of the United States of America 103, 11201-11205.

Liu, Z., Pagani, M., Zinniker, D., Deconto, R., Huber, M., Brinkhuis, H., Shah, S.R., Leckie, R.M., Pearson, A., 2009. Global cooling during the eocene-oligocene climate transition. Science 323, 1187-1190.

Miller, K.G., Fairbanks, R.G., Mountain, G.S., 1987. Tertiary oxygen isotope synthesis, sea level history, and continental margin erosion. Paleoceanography 2, 1-19.

NCDC, 2009. Surface Data-Global Summary of the Day:1957-2009.

Passey, B.H., Robinson, T.F., Ayliffe, L.K., Cerling, T.E., Sponheimer, M., Dearing, M.D., Roeder, B.L., Ehleringer, J.R., 2005. Carbon isotope fractionation between diet, breath CO2, and bioapatite in different mammals. Journal of Archaeological Science 32, 1459-1470.

Pearson, P.N., Foster, G.L., Wade, B.S., 2009. Atmospheric carbon dioxide through the EoceneOligocene climate transition. Nature 461, 1110-1113.

Retallack, G.J., 2007. Cenozoic paleoclimate on land in North America. The Journal of Geology 115, 271-294.

Rind, D., 1986. The dynamics of warm and cold climates. Journal of the atmospheric sciences 43, 3-25.

Schouten, S., Eldrett, J., Greenwood, D.R., Harding, I., Baas, M., Damsté, J.S.S., 2008. Onset of long-term cooling of Greenland near the Eocene-Oligocene boundary as revealed by branched tetraether lipids. Geology 36, 147.

Storer, J.E., 1994. A latest Chadronian (late Eocene) mammalian fauna from the Cypress Hills, Saskatchewan. Canadian Journal of Earth Sciences 31, 1335-1341.

STORER, J.E., 1996. 12. Eocene-Oligocene Faunas of the Cypress Hills Formation, Saskatchewan. The Terrestrial Eocene-Oligocene Transition in North America, 240.

Suarez, C.A., González, L.A., Ludvigson, G.A., Cifelli, R.L., Tremain, E., 2012. Water utilization of the Cretaceous Mussentuchit Member local vertebrate fauna, Cedar Mountain Formation, Utah, USA: Using oxygen isotopic composition of phosphate. Palaeogeography, Palaeoclimatology, Palaeoecology 313-314, 78-92.

Terry, D.O., 2001. Paleopedology of the Chadron formation of northwestern Nebraska; implications for paleoclimate change in the North American mid-continent across the EoceneOligocene boundary. Palaeogeography, Palaeoclimatology, Palaeoecology 168, 1-38.

Tipple, B.J., Meyers, S.R., Pagani, M., 2010. Carbon isotope ratio of Cenozoic CO2: A comparative evaluation of available geochemical proxies. Paleoceanography 25.

Tütken, T., Vennemann, T.W., Janz, H., Heizmann, E.P.J., 2006. Palaeoenvironment and palaeoclimate of the Middle Miocene lake in the Steinheim basin, SW Germany: A reconstruction from $\mathrm{C}$, O, and $\mathrm{Sr}$ isotopes of fossil remains. Palaeogeography, Palaeoclimatology, Palaeoecology 241, 457-491.

van der Merwe, N.J., Medina, E., 1991. The canopy effect, carbon isotope ratios and foodwebs in Amazonia. Journal of Archaeological Science 18, 249-259.

Wade, B.S., Houben, A.J.P., Quaijtaal, W., Schouten, S., Rosenthal, Y., Miller, K.G., Katz, M.E., Wright, J.D., Brinkhuis, H., 2012. Multiproxy record of abrupt sea-surface cooling across the Eocene-Oligocene transition in the Gulf of Mexico. Geology 40, 159-162.

Xiao, G.Q., Abels, H.A., Yao, Z.Q., Dupont-Nivet, G., Hilgen, F.J., 2010. Asian aridification linked to the first step of the Eocene-Oligocene climate Transition (EOT) in obliquity-dominated terrestrial records (Xining Basin, China). Climate of the Past 6, 501-513. 
Zachos, J., Pagani, M., Sloan, L., Thomas, E., Billups, K., 2001. Trends, rhythms, and aberrations in global climate 65 Ma to present. Science 292, 686-693.

Zanazzi, A., Kohn, M.J., 2008. Ecology and physiology of White River mammals based on stable isotope ratios of teeth. Palaeogeography, Palaeoclimatology, Palaeoecology 257, 22-37. Zanazzi, A., Kohn, M.J., MacFadden, B.J., Terry, D.O., 2007. Large temperature drop across the Eocene-Oligocene transition in central North America. Nature 445, 639-642.

Zanazzi, A., Kohn, M.J., Terry, D.O., 2009. Biostratigraphy and paleoclimatology of the EoceneOligocene boundary section at Toadstool Park, northwestern Nebraska, U. S. A. Geological Society of America Special Paper. 
Figure 1

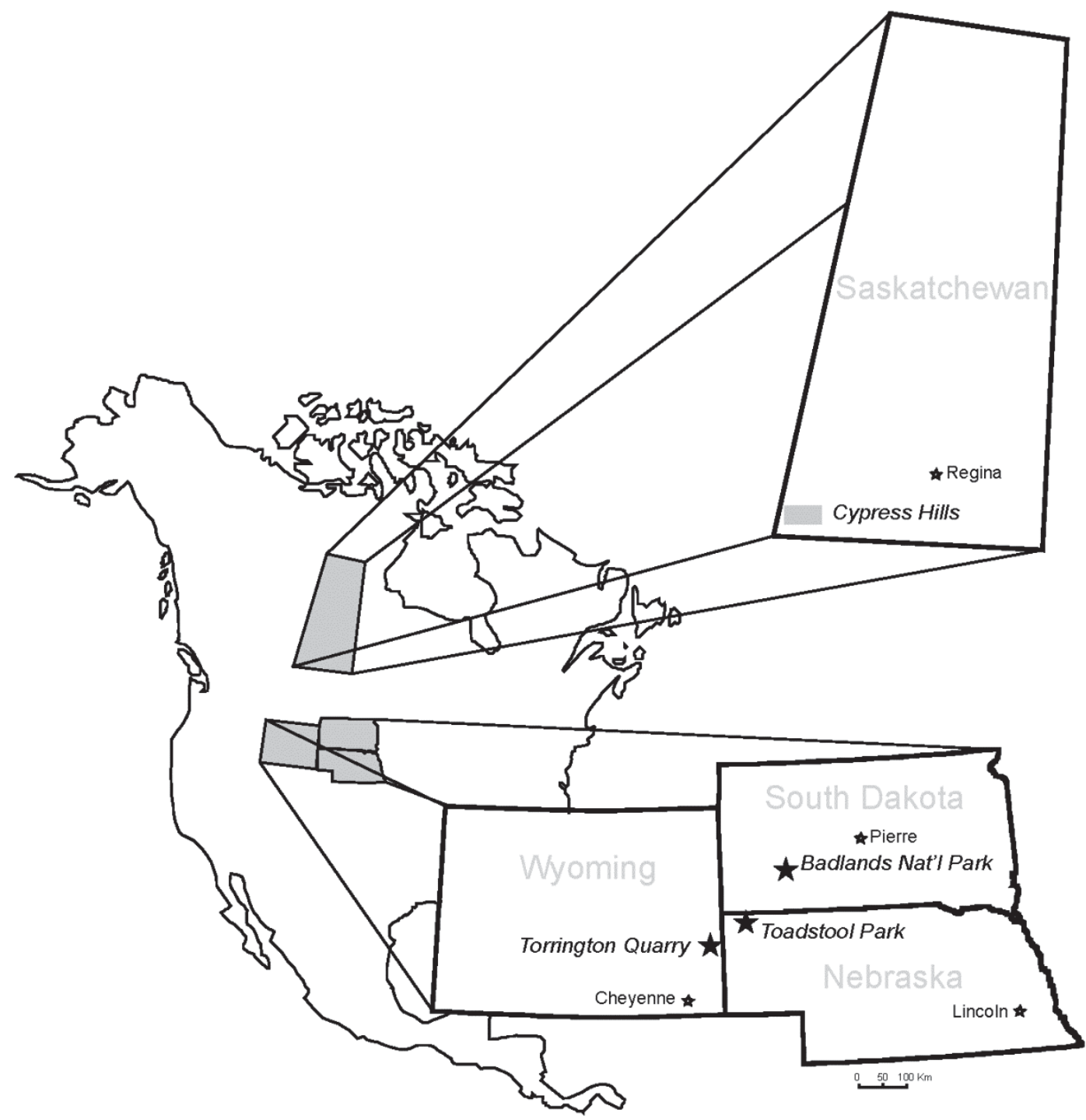


Figure 2

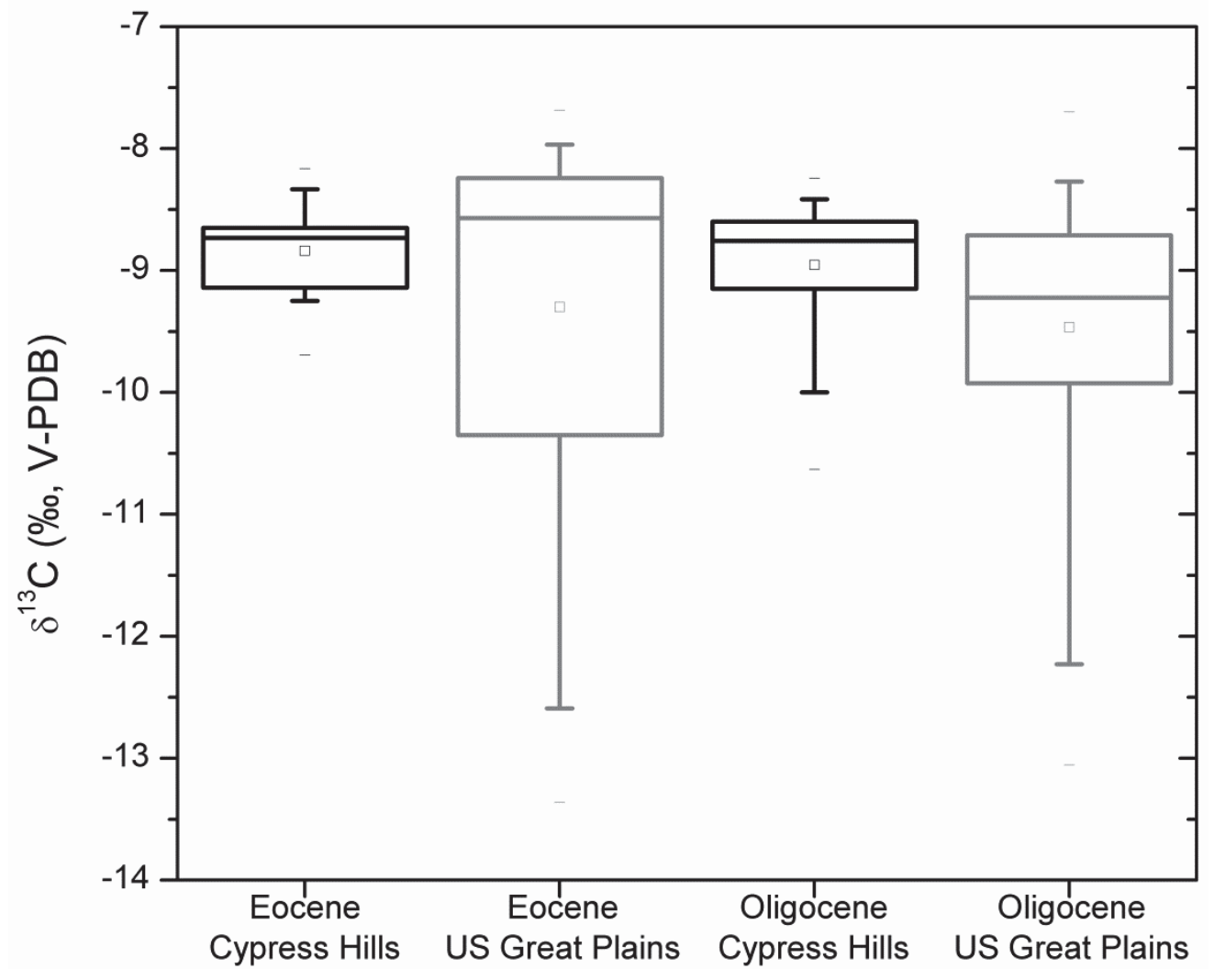


Figure 3

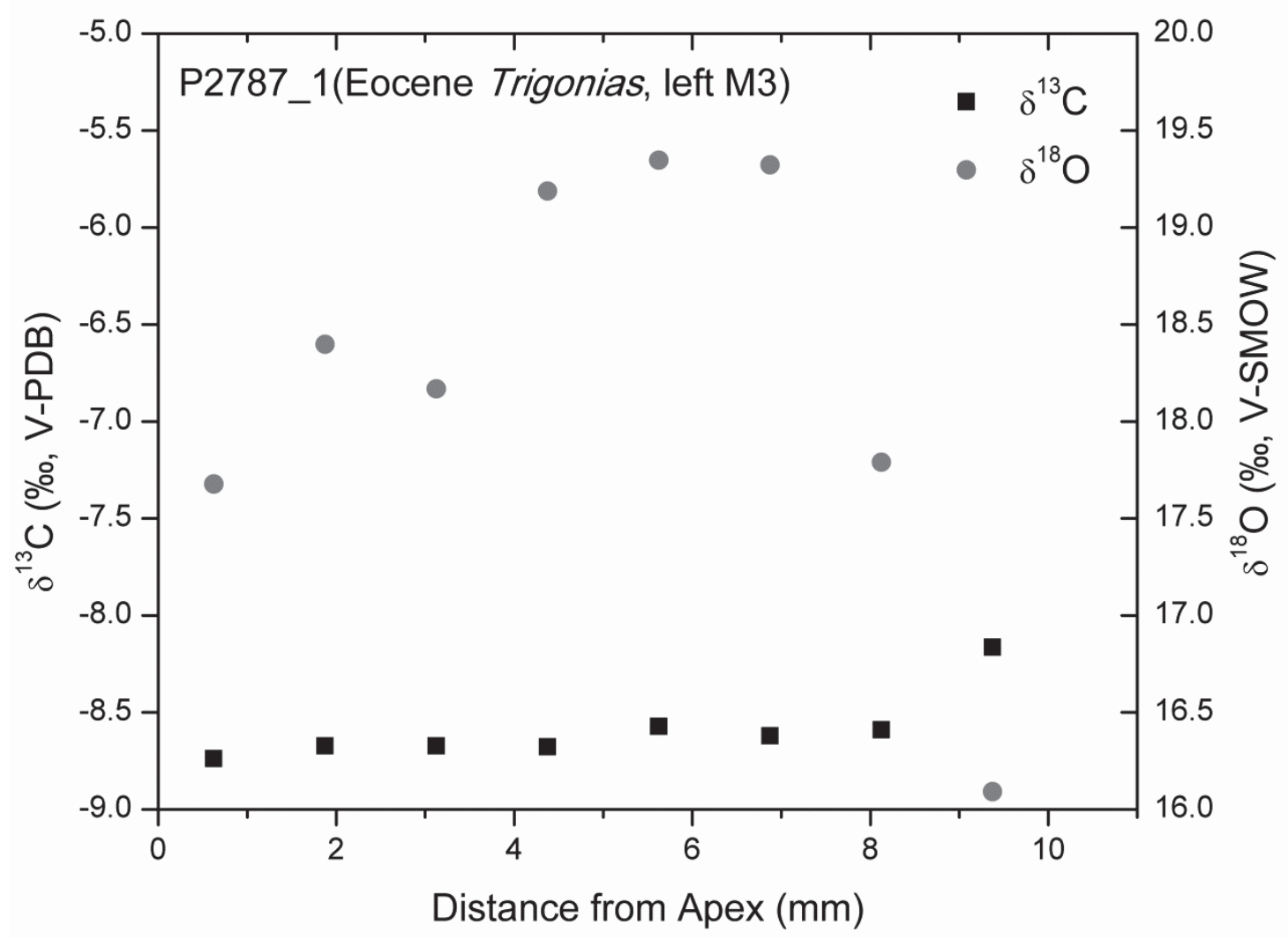


Figure 4

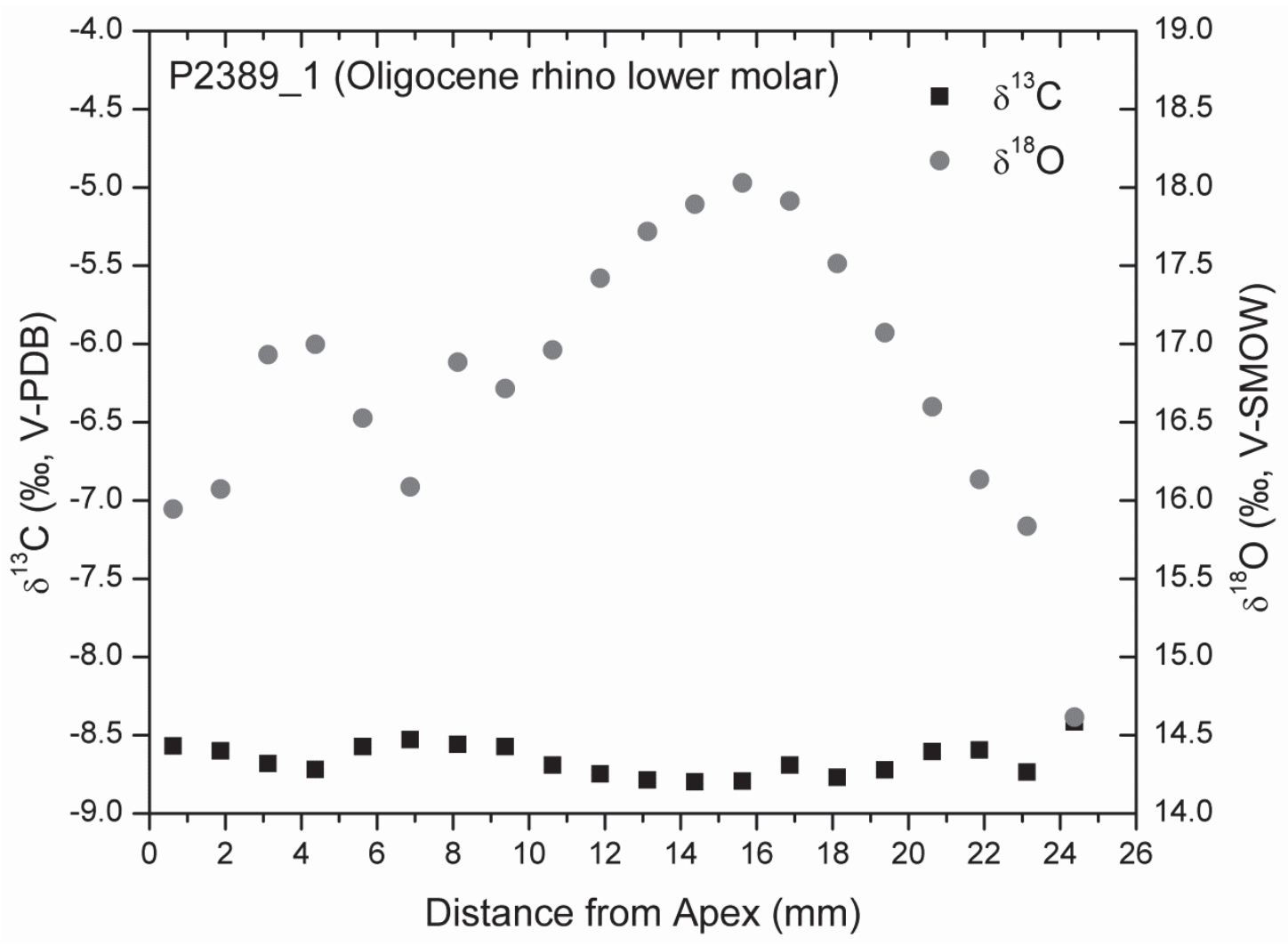


This is an author-produced, peer-reviewed version of this article. The final, definitive version of this document can be found online at Palaeogeography, Palaeoclimatology, Palaeoecology, published by Elsevier. Copyright restrictions may apply. doi: 10.1016/j.palaeo.2014.10.024

Figure 5

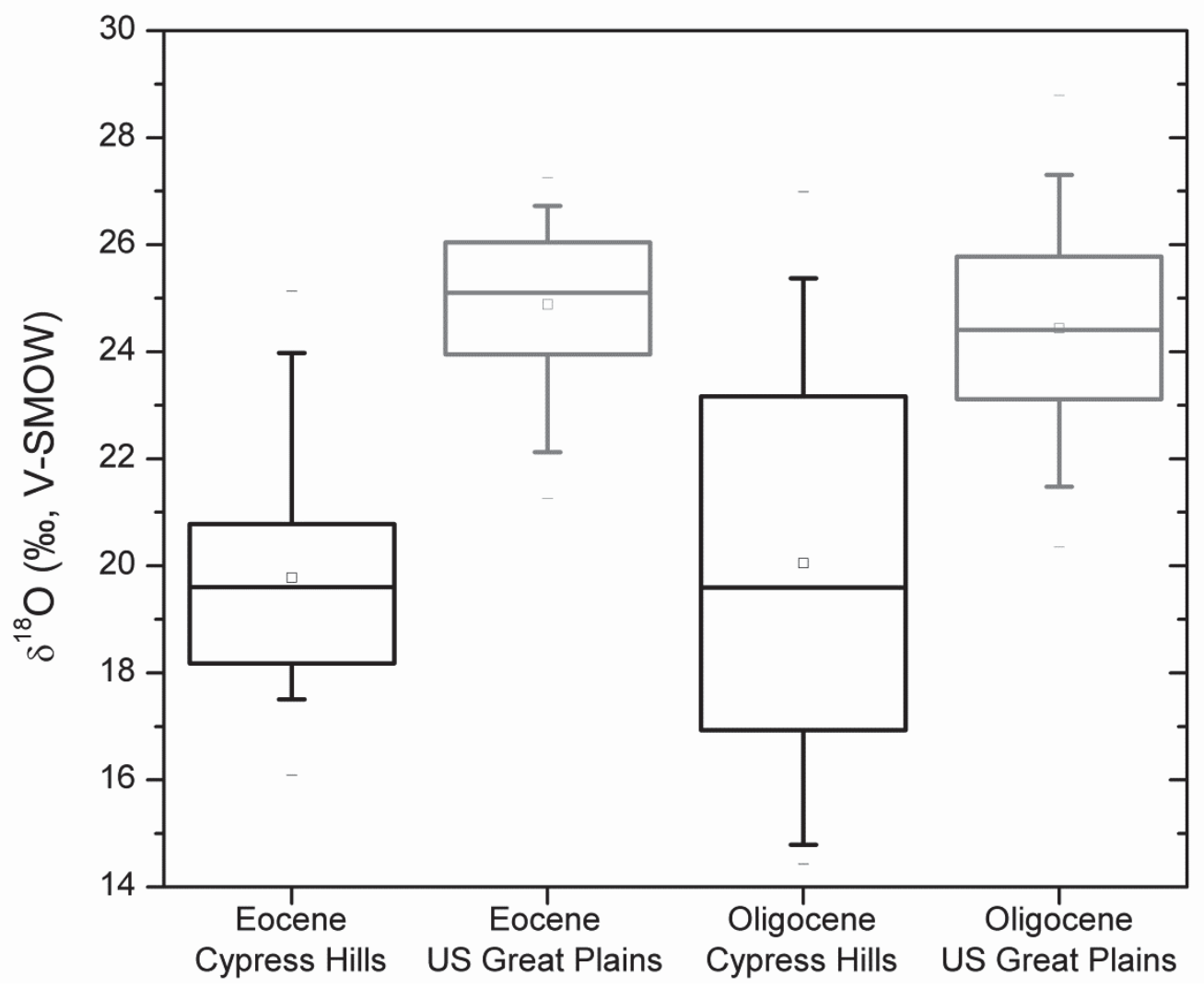


Figure 1. Map showing the sampling sites of this study in the Cypress Hills along with those of Zanazzi et al. (2007, 2009) and Zanazzi and Kohn (2008) in the US Great Plains (Toadstool Park, Nebraska; Badlands National Park, South Dakota; Torrnigton Quarry, Wyoming).

Figure 2. Box and whiskers plots of Eocene and Oligocene peryssodactyl $\delta^{13} \mathrm{C}$ in the Cypress Hills and in the US Great Plains. The lower and upper sides of the boxes indicate the lower and upper quartile, respectively. Inside the boxes, the solid lines indicate the median and the hollow squares the mean. The length of the whiskers indicates the 5 to 95-percentile range. Outside the boxes, the segments indicate the minimum and maximum values. Eocene and Oligocene average $\delta^{13} \mathrm{C}$ values in the Cypress Hills are indistinguishable, suggesting no major change in MAP across the EOT. Average $\delta^{13} \mathrm{C}$ values in the Cypress Hills are slightly higher than those in the US Great Plains in both the Eocene and Oligocene, suggesting slightly drier conditions at higher latitudes.

Figure 3. $\delta^{13} \mathrm{C}$ vs. distance along tooth for an Eocene rhino (Trigonias) tooth from the Cypress Hills. The intra-tooth profiles indicate a very small variability in $\delta^{13} \mathrm{C}$ but a large variability in $\delta^{18} \mathrm{O}$, which suggests substantial temperature seasonality in the Eocene in the Cypress Hills.

Figure 4. $\delta^{13} \mathrm{C}$ vs. distance along tooth for an Oligocene rhino molar from the Cypress Hills. Similar to the Eocene tooth, the intra-tooth profiles show small and large variability in $\delta^{13} \mathrm{C}$ and $\delta^{18} \mathrm{O}$, respectively.

Figure 5. Box and whiskers plots of Eocene and Oligocene peryssodactyl $\delta^{18} \mathrm{O}$ in the Cypress Hills and in the US Great Plains. The lower and upper sides of the boxes indicate the lower and upper quartile, respectively. Inside the boxes, the solid lines indicate the median and the hollow squares the mean. The length of the whiskers indicates the 5 to 95-percentile range. Outside the boxes, the segments indicate the minimum and maximum values. Eocene and Oligocene average $\delta^{18} \mathrm{O}$ values in the Cypress Hills are indistinguishable, suggesting no major change in rainwater $\delta^{18} \mathrm{O}$ across the EOT. Average $\delta^{18} \mathrm{O}$ values in the Cypress Hills are lower than those in the US Great Plains, suggesting the presence of a latitudinal MAT gradient in both the Eocene and Oligocene. The difference between the values in the Cypress Hills and in the US Great Plains is however constant, suggesting no major change in latitudinal MAT gradients across the EOT in North America 
Table 1. Summary statistics of the carbon and oxygen isotope compositions of the Cypress Hills Eocene teeth analyzed in this study.

Table 2. Summary statistics of the carbon and oxygen isotope compositions of the Cypress Hills Oligocene teeth analyzed in this study. 
Table 1

\begin{tabular}{|c|c|c|c|c|c|c|c|c|}
\hline Tooth ID & Taxon & Site & $\begin{array}{l}\text { Tooth } \\
\text { Position } \\
\end{array}$ & $\begin{array}{c}\mathrm{n} \\
\text { subsamples }\end{array}$ & $\begin{array}{c}\text { Mean } \delta^{13} \mathrm{C}(\% \circ, \mathrm{V}- \\
\text { PDB) } \\
\end{array}$ & $\begin{array}{l}\text { S.D. } \\
(\% \circ)\end{array}$ & $\begin{array}{c}\text { Mean } \delta^{18} \mathrm{O}(\% \circ, \mathrm{V}- \\
\text { SMOW) } \\
\end{array}$ & $\begin{array}{l}\text { S.D. } \\
(\% \circ)\end{array}$ \\
\hline P2787_1 & Trigonias osborni & Bud & left M3 & 8 & -8.6 & 0.2 & 18.2 & 1.1 \\
\hline P2551.29 & Rhino & KSW & right $\mathrm{p} 4$ & 2 & -8.7 & 0.0 & 20.8 & 0.4 \\
\hline P2551.29 & Rhino & KSW & right $\mathrm{p} 4$ & 13 & -8.6 & 0.1 & 20.2 & 0.8 \\
\hline $\mathrm{CH} 71-1$ & Rhino & Irish Springs & ? & 14 & -9.1 & 0.1 & 18.2 & 0.6 \\
\hline P2363.3 & Mesohippus & Parker Ranch/Alexander Ranch & $\begin{array}{l}\text { right } \mathrm{M} 1 \text { or } \\
\mathrm{M} 2\end{array}$ & 3 & -8.8 & 0.0 & 20.5 & 0.3 \\
\hline P 2595.8 & Mesohippus & Bud & $\begin{array}{l}\text { right M1 or } \\
\text { M2 }\end{array}$ & 2 & -9.2 & 0.0 & 22.7 & 1.0 \\
\hline P 2549.5 & Mesohippus & Bud & left $\mathrm{m} 1$ or $\mathrm{m} 2$ & 2 & -9.6 & 0.1 & 23.3 & 0.1 \\
\hline P2754.4 & Mesohippus & Conglomerate Creek & $\begin{array}{l}\text { right } \mathrm{M} 1 \text { or } \\
\mathrm{M} 2\end{array}$ & 3 & -9.2 & 0.1 & 20.5 & 1.9 \\
\hline P1585.1542 & Mesohippus propinquus & Calf Creek & left P4 or M? & 4 & -8.6 & 0.2 & 18.6 & 1.2 \\
\hline P1585.1546 & Mesohippus propinquus & Calf Creek & right $\mathrm{m} 2$ & 3 & -8.4 & 0.1 & 24.4 & 0.6 \\
\hline
\end{tabular}

Table 2

\begin{tabular}{|c|c|c|c|c|c|c|c|c|}
\hline Tooth ID & Taxon & Site & $\begin{array}{c}\text { Tooth } \\
\text { Position }\end{array}$ & $\begin{array}{c}\mathrm{n} \\
\text { subsamples }\end{array}$ & $\begin{array}{c}\text { Mean } \delta^{13} \mathrm{C}(\% \circ, \mathrm{V}- \\
\text { PDB) }\end{array}$ & $\begin{array}{l}\text { S.D. } \\
(\% \circ)\end{array}$ & $\begin{array}{c}\text { Mean } \delta^{18} \mathrm{O}(\% \text {, V- } \\
\text { SMOW) }\end{array}$ & $\begin{array}{l}\text { S.D. } \\
(\% \circ)\end{array}$ \\
\hline P2389_1 & Rhino & Fossil Bush & $\begin{array}{l}\text { right } \mathrm{m} 1 \text { or } \\
\mathrm{m} 2\end{array}$ & 20 & -8.7 & 0.1 & 16.8 & 0.9 \\
\hline P2442.70 & Rhino & Fossil Bush & $\begin{array}{l}\text { right } m 1 \text { or } \\
\mathrm{m} 2\end{array}$ & 10 & -8.5 & 0.2 & 20.5 & 0.9 \\
\hline $\mathrm{CH} 37-2$ & Rhino & Fossil Bush & ? & 9 & -8.8 & 0.2 & 17.0 & 2.1 \\
\hline P2707.18 & Mesohippus & Fossil Bush & left $\mathrm{p} 3$ or $\mathrm{p} 4$ & 8 & -9.5 & 0.2 & 25.0 & 1.1 \\
\hline P 1011.2 & Mesohippus & Anxiety Butte & $\begin{array}{l}\text { right } \mathrm{m} 1 \text { or } \\
\mathrm{m} 2\end{array}$ & 7 & -9.8 & 0.6 & 23.9 & 2.0 \\
\hline P2442.26 & Mesohippus & Fossil Bush & $\begin{array}{l}\text { right } \mathrm{m} 1 \text { or } \\
\mathrm{m} 2\end{array}$ & 4 & -8.8 & 0.1 & 22.2 & 2.0 \\
\hline ROM A575 & Mesohippus bairdii & Fossil Bush & right P2 & 2 & -10.1 & 0.3 & 21.1 & 0.8 \\
\hline
\end{tabular}


This is an author-produced, peer-reviewed version of this article. The final, definitive version of this document can be found online at Palaeogeography, Palaeoclimatology, Palaeoecology, published by Elsevier. Copyright restrictions may apply. doi: 10.1016/j.palaeo.2014.10.024

\begin{tabular}{|l|l|l|l|l|l|l|l|l|} 
& & right $\mathrm{m} 1$ or & & & \\
$\mathrm{m} 2$ & Anxiety Butte & 3 & -8.8 & 0.0 & 23.1 \\
\hline P2225.26 & Mesohippus & Fossil Bush & right P1 & 1 & -9.1 & NA & 27 \\
\hline
\end{tabular}


This is an author-produced, peer-reviewed version of this article. The final, definitive version of this document can be found online at Palaeogeography, Palaeoclimatology, Palaeoecology, published by Elsevier. Copyright restrictions may apply. doi: 10.1016/j.palaeo.2014.10.024

Highlights-Zanazzi et al. 2014

- Eocene and Oligocene teeth from Saskatchewan were analyzed for their $\delta^{18} \mathrm{O}$ and $\delta^{13} \mathrm{C}$

- $\delta^{18} \mathrm{O}$ of meteoric precipitation did not change in the Eocene vs. Oligocene

- Latitudinal temperature gradients did not change in the Eocene vs. Oligocene

- Mean annual precipitation did not change in the Eocene vs. Oligocene

- Temperature seasonality greatly increased from the Eocene to the Oligocene 